\title{
日本海上の爆弾低気圧に起因する 高波の発達機構
}

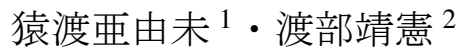 \\ 1 正会員 北海道大学助教 大学院工学研究院 $(060-8628$ 札幌市北区北 13 条西 8 丁目) \\ E-mail: saruwata@eng.hokudai.ac.jp \\ 2 正会員 北海道大学准教授 大学院工学研究院 (060-8628 札幌市北区北 13 条西 8 丁目) \\ E-mail: yasunori@eng.hokudai.ac.jp
}

\begin{abstract}
急速な気圧の低下を伴い冬季に特に多く発生する爆弾低気圧は発生頻度, 強度ともに増加傾向にあると言わ れており，近年の冬季の気候を決定する重要なファクターとなっている. 2014 年 12 月には日本海上で二つの 大きな爆弾低気圧が相次いで発生し, 北陸から北海道にかけての日本海側の広い範囲に高波被害をもたらした。 本研究では過去 36 年間の気象再解析データと過去 19 年間に渡る波浪観測データを基に近年日本周辺における 冬季の低気圧が頻発化傾向にあり，それに伴い高波リスクが増大していることを示す。さらに波浪推算結果か ら 2014 年 12 月に発生した爆弾低気圧に伴う高波の発生機構を説明し, 本イベントがこれまでの典型的な西高 東低の冬型の気圧配置に伴う高波とは全く異なる特徴を有していた事を示す.
\end{abstract}

Key Words: High waves, explosive cyclogenesis, winter cyclones, Simulating Waves Nearshore, wave growth rate

\section{1.はじめに}

近年 24 時間で $24 \mathrm{hPa}$ 以上の急速な中心気圧の低下 を伴い形成された強い低気圧である爆弾低気圧の発生 頻度が日本周辺を含む世界各地で増加している ${ }^{1) 2)}$. 頻 度だけでなく冬季の低気圧強度も増大傾向にあり，太 平洋中央部と東部において暴風イベント時の高波が増 大しているとの報告もある ${ }^{3)}$. 2014 年 12 月 1-3 日と 16-17日に日本海西部において発達した爆弾低気圧は いずれも日本海上の低気圧としては稀な程中心気圧が 低下したもので, これらにより北海道南部の江差町で 海岸道路の法面浸食被害が発生した他, 福井や山形の 海岸道路で越波による交通規制が敷かれる等, 各地で 交通障害が発生した（図-1）。爆弾低気圧の頻発化に 伴い，従来日本海冬季に想定されてきた典型的な西高 東低の冬型の気圧配置に伴う来襲波とは全く異なる特 徵をもつ暴風高波による被害が懸念され，これまで経 験してこなかった高波発生機構の解明とそれに対する 防災対策が今後求められる。

本研究は過去 36 年の気象再解析データから日本周辺 を通過する冬季の低気圧の特徴の遷移を調べるととも に，爆弾低気圧に起因する高波の統計的特徵を明らか にする。ささに過去にない新たなタイプの高波被害をも たらした 2014 年 12 月の二つの爆弾低気圧を例に, 日 本海を北上する爆弾低気圧に伴う高波の発達過程の特 徵を明らかにすることを目的とする。

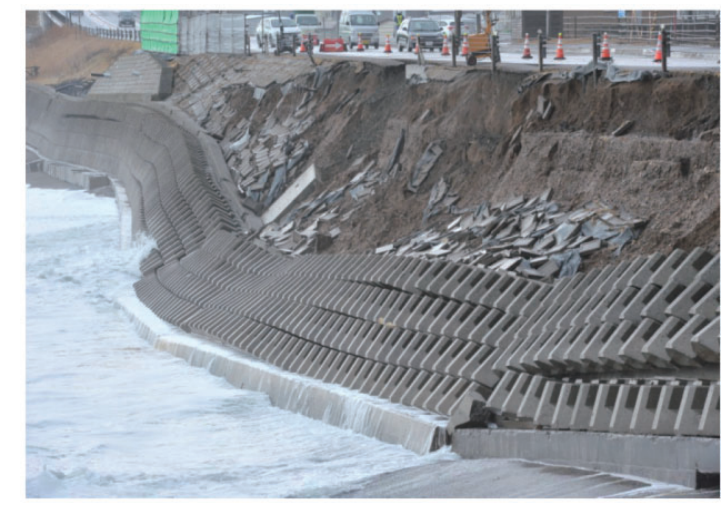

図-1 高波により被災した海岸道路（北海道開発局函館開建 報道資料より。2014 年 12 月 4 日，江差町）。

\section{2. 気象, 海象の遷移}

\section{(1) 解析方法}

日本周辺で冬季に発達する低気圧の中心気圧や発 生頻度, 経路の変化を気象庁が提供する GPV デー 夕 JMA-MSM（解像度 $0.0625 \times 0.0500$ 度，2001-2015 年) と ECMWF (European Centre for Medium-Range Weather Forecasts) が提供する気象再解析データ ERA Interim（解像度：0.75 度，1979-2015 年）を基に調べ た. また爆弾低気圧通過イベントに対する波高の変化を 国土交通省港湾局が運用する Nowphas による観測デー タを基に調査した。ここで爆弾低気圧通過 1 イベント 

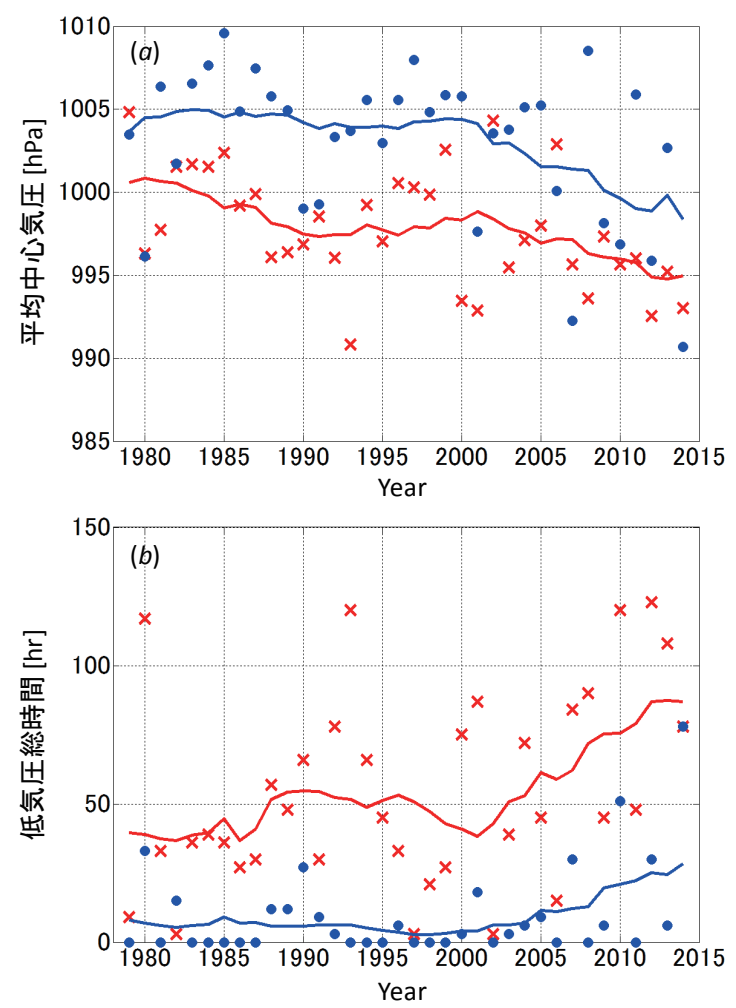

図-2 日本付近の太平洋上（赤）と日本海上（青）で各年 12 月に発達した低気圧の平均中心気圧 $(a)$ 中心気圧が標準 大気圧から $24 \mathrm{hPa}$ 以上低下した総時間 $(b)$. 実線は 11 年間移動平均。

は九州大学爆弾低気圧情報データベースで定義される 低気圧の発生から消滅までの期間とした。

\section{（2）日本周辺における冬季の気象海象の近年の傾向}

爆弾低気圧情報データベースによると，冬季を通し て数多く発生する爆弾低気圧は特に 12 月と 3 月に発 生個数のピークを有する. そこで本研究では 1979 年以 降の 12 月の日本周辺における太平洋上，並びに日本海 上で発生した低気圧の中心気圧の変遷を調べた（図-2 (a)）。ここでは $\mathrm{N} 40^{\circ}-50^{\circ}, \mathrm{E} 130^{\circ}-140^{\circ}$ の範囲を日本海 上, $\mathrm{N} 40^{\circ}-50^{\circ}, \mathrm{E} 140^{\circ}-150^{\circ}$ の範囲を太平洋上と定義し ている．それぞれの 11 年間移動平均により近年のトレ ンドを見てみると，概ね 2000 年を境に爆弾低気圧の中 心気圧は低下傾向に転じていることが分かる。また， 2000 年以前は典型的な西高東低の冬型の気圧配置が形 成されてきたことにより日本海上よりも太平洋上の方 が低気圧の中心気圧が平均 $6 \mathrm{hPa}$ 程低い傾向にあった が，2000 年以降は西高東低以外のパターンの低気圧が 日本海上で発生し，太平洋側に匹敵する強度にまで発 達する頻度が増しており，両海上の気圧差が相対的に小 さくなっている．図-2 $(b)$ は 12 月に発生した低気圧の 中心気圧が標準大気圧より $24 \mathrm{hPa}$ 以上低下した総時間 の変遷である．低気圧が強化傾向に転じた 2000 年以降,
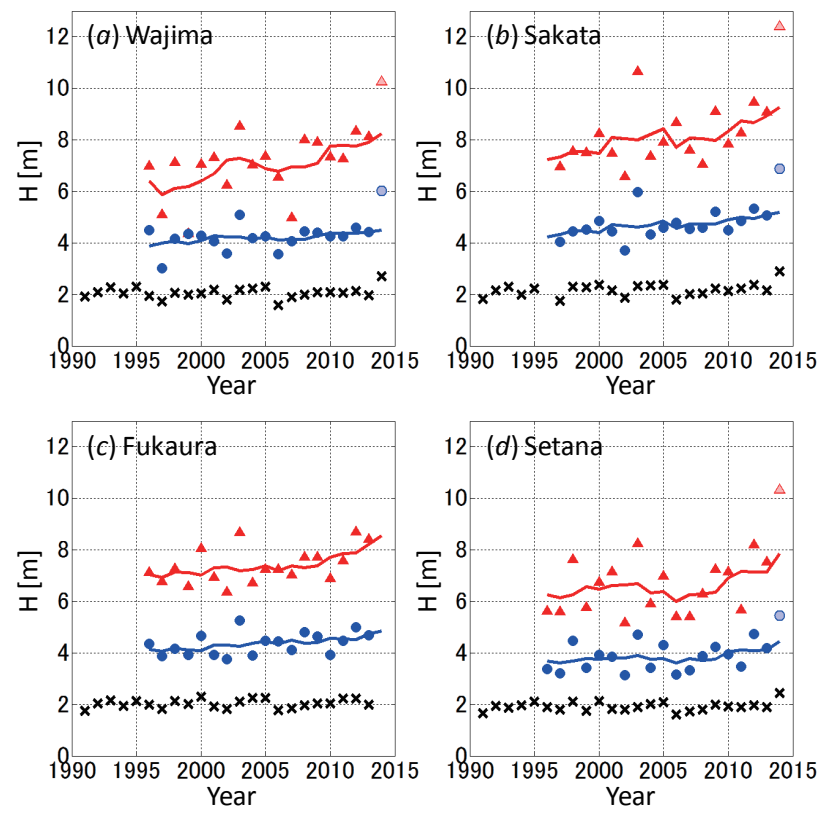

図-3 Nowphas により観測された有義波高（黒），爆弾低気 圧通過時の最大有義波高（青）と最大最高波高（赤）の 12 月における平均. 実線は 5 年間移動平均.

その存続時間も延長傾向にあることが明らかとなった。

日本海側の 7 点の観測点（鳥取，金沢，輪島，酒田， 深浦，瀬棚，留萌）における Nowphas による観測デー タから，暴風イベントの強化と延長の影響が波浪場に 与えた影響について調査した。図-3 に示寸のは 1991 年以降の 12 月における平均有義波高と, 爆弾低気圧通 過イベント中のピーク有義波高とピーク最高波高の平 均值の変遷である。ただし本稿を執筆する 2015 年 5 月 現在，2014 年 12 月の爆弾低気圧情報はデータベース に未公開であるため，ここでは本研究で波浪追算を行 う二つの爆弾低気圧通過時のピーク波高の平均を 2014 年の参考データとしてプロットしている。 また図中に は 2014 年以外のデータの 5 年間移動平均もプロットし ている。いずれの観測点においても有義波高の1ヶ月平 均值には顕著な変化は見られないが，日本海側の広い 範囲において爆弾低気圧通過イベント時のピーク有義/ 最高波高に緩やかな増大トレンドが見られた。これは 図-2 にて示された冬季の低気圧の強大化と暴風イベン 卜の総時間の延長に起因するものであり，日本海沿岸 において冬季の高波リスクが増大していることを示す ものである

\section{2014 年 12 月の爆弾低気圧による高波}

\section{(1) 波浪推算モデル}

2014 年 12 月 2 日と 17 日前後に日本海上で二つの特 徵的な爆弾低気圧が発達したが，本研究ではこれらを それぞれ低気圧 L1, L2 とし，それらがもたらした高波 


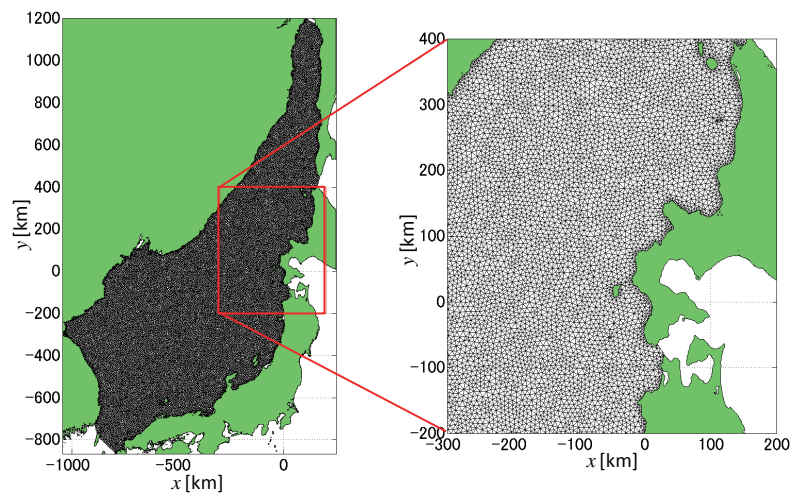

図-4 計算領域と計算グリッド.
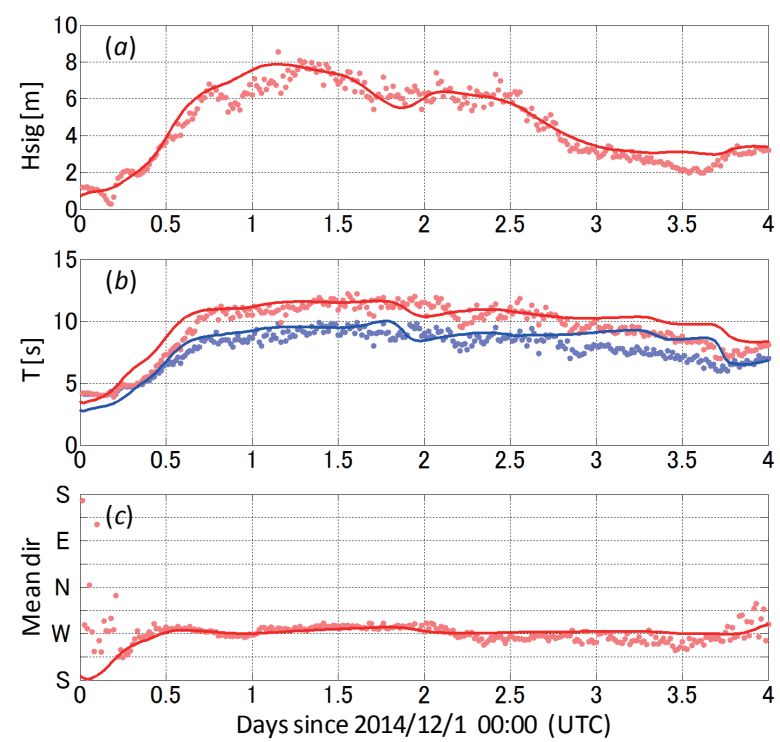

図-5 本研究の計算結果（実線）とNowphasによる酒田にお ける観測結果（点）との比較の一例. (a) 有義波高. $(b)$ 有義波周期（赤）と平均周期（青）. (c) 平均波向き.

の発達過程を波浪推算モデル SWAN (Simulating Waves Nearshore ${ }^{4)}$, Ver. 41.01) を用いて再現した。風速場は本 研究の計算領域全域をカバーし波浪推算モデルへのイ ンプットとしてしばしば用いられる NCEP Final Analysis（時間間隔 6 時間）により，また海底地形は BODC (British Oceanographic Data Centre) が提供する GEBCO

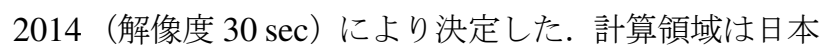
海全域とし, 計算グリッドは平均面積 $20 \mathrm{~km}^{2}$ の三角形 非構造格子とした（図-4）。 日本海と東シナ海, 太平洋, オホーツク海との間の計算領域境界は閉境界であり領域 外からの波浪スペクトルのインプットは与えていない. 計算期間は低気圧 L1 については 2014/12/1 00:00 (UTC) から 4 日間, L2 については 2014/12/15 12:00 (UTC) か ら 4.5 日間とした.

SWAN による計算結果の検証のため, 前述の日本海

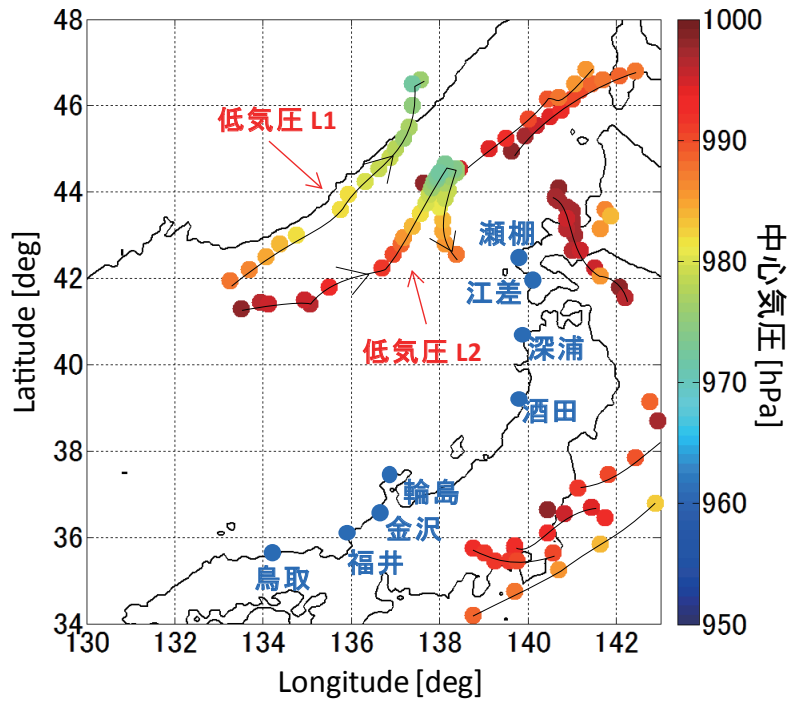

図-6 2014 年 12 月に日本海上を通過した低気圧の中心の経 路. 色は中心気圧を表す。

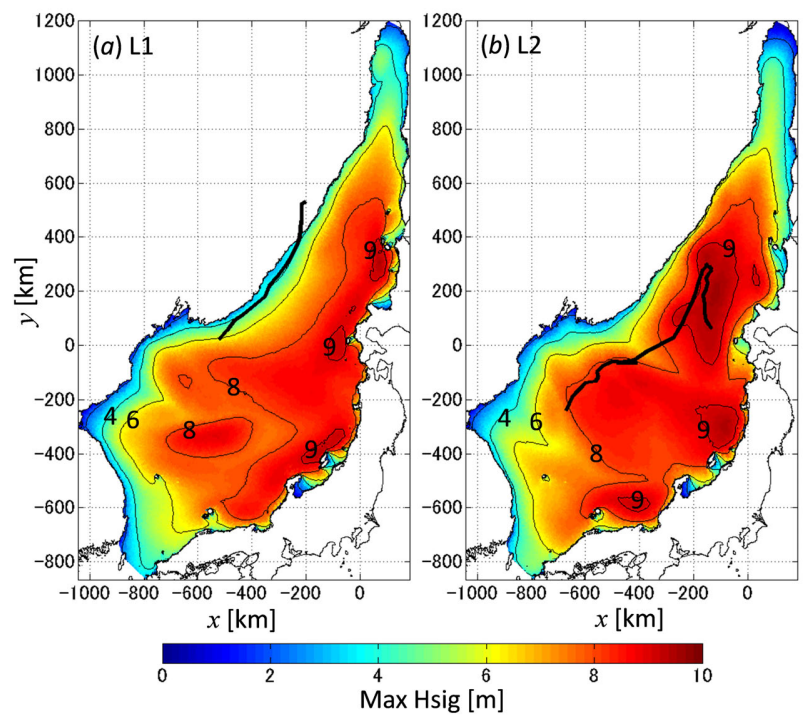

図-7 本計算により得られた $(a) \mathrm{L} 1,(b) \mathrm{L} 2$ イベント間での最 大有義波高の分布. 黒太線は各低気圧の中心経路を表す.

側の Nowphasによる観測点 7 点における波浪観測結果 と比較した（図-5 は一例）。波高と周期の実測值との 相関係数は有義波高 0.94-0.99, 有義波周期 0.90-0.96, 平均周期 0.84-0.94 と高い相関を示しており，本研究の 計算結果はイベント中の波浪場を妥当に再現している と考える.

\section{（2）日本海を縱断する爆弾低気圧に伴う高波の特徵}

図-6 は2014 年 12 月中に発生した低気圧の経路と 中心気圧を示したものである．爆弾低気圧 L1, L2 はと もに，大陸上の強い高気圧に進路をブロックされ，20 $\mathrm{km} / \mathrm{hr}$ 程度のゆっくりとした速度で日本海上を北上し 

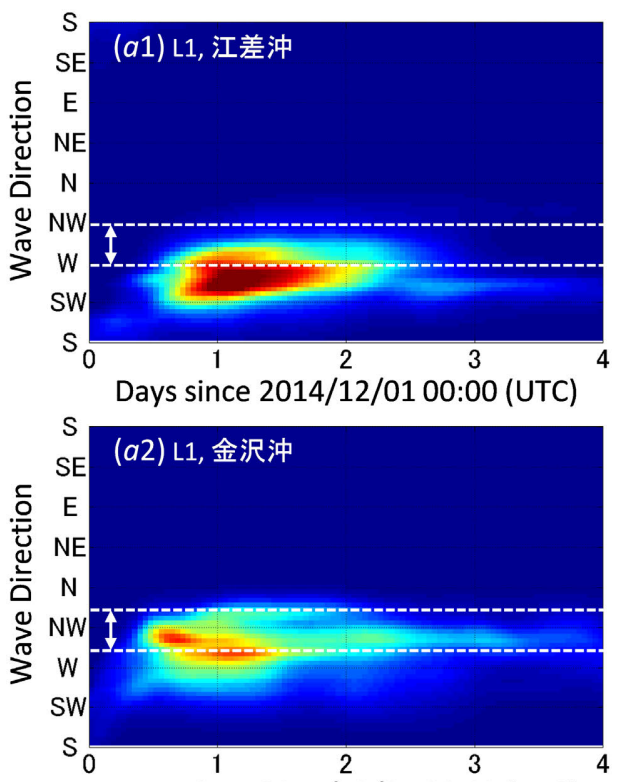

Days since 2014/12/01 00:00 (UTC)
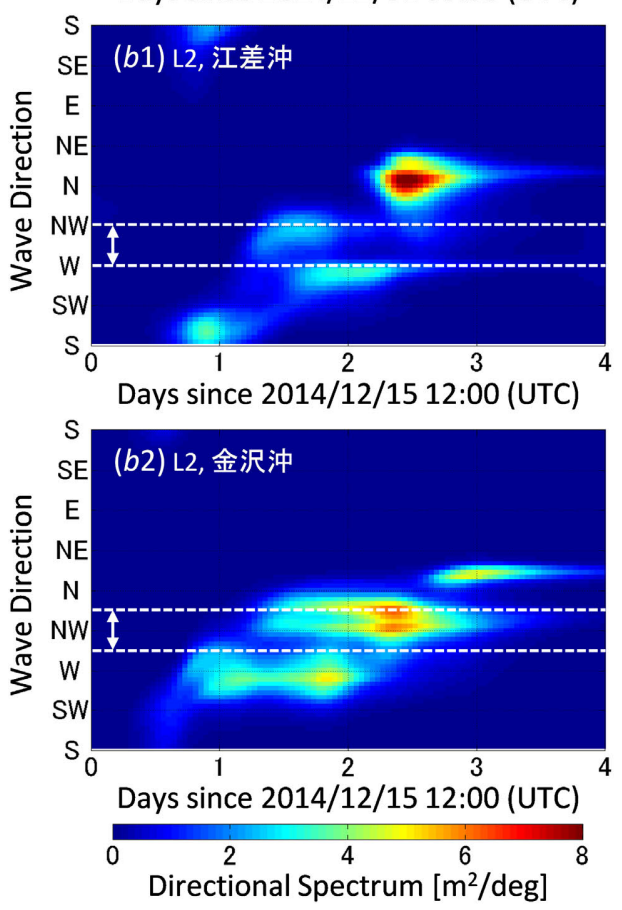

図-8 低気圧 L1 (a), L2 (b) 通過に伴う波の方向スペクトルの 時間変化. 白点線と両矢印は各地点における典型的な 冬季の波向きのレンジを表す.

た．両低気圧はともに，前述の過去 36 年間の気象再解 析データと比較しても（図-2 (a) 参照) 冬季にこの経路

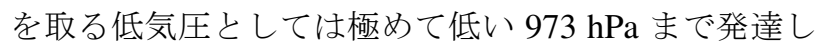
た。本計算により得られた L1, L2 通過時の最大有義波 高の分布を図-7 に示寸.日本海上に強い西風を伴うこ れらの低気圧は南西から西寄りの波浪を発達させ，そ の結果北陸から北海道にかけての日本海沿岸の広い範 囲に最大有義波高 8-9 m にもなる高波を来襲させた.

低気圧 L1, L2 通過中の江差及び金沢沖における波浪
表-1 有義波高発達率（単位：m/hr）。

\begin{tabular}{c|ccc}
\hline & 1994 年以前 ${ }^{6)}$ & L1 & L2 \\
\hline 留萌 & 0.070 & 0.602 & 0.273 \\
深浦 & 0.072 & 0.647 & 0.428 \\
酒田 & 0.111 & 0.641 & 0.473 \\
輪島 & 0.060 & 0.513 & 0.361 \\
金沢 & 0.064 & 0.383 & 0.471 \\
鳥取 & 0.067 & 0.397 & 0.398 \\
\hline
\end{tabular}

の方向スペクトルの変化を図-8 に示す，日本海西部を 真っ直ぐ北上した低気圧 L1 は，進路の背後に強い西風 を伴い日本海上には南西から西寄りの波浪を発達させ た（図-8 (a)）。一方 L2 通過中は低気圧の移動に伴う 風向きの変化の影響を受け, 各地で波向きが時々刻々と 変化し, 多方向からの波が重畳することにより多峰型 方向スペクトルが発達した（図-8 $(b))$. いずれのイ心゙ ントにおいても各地で波の高い状態が丸二日程度継続 した．前述の通り L1, L2 は日本海でこれまでに発生し てきた低気圧とは異なる特徵を有しており, 本イベン 卜中の波向きは，例えば永井ら 5) により報告される冬 季の典型的な卓越波向きとは必ずしも一致していない (図-8 白線)。これまでの経験に基き想定してきた方向 以外からの高波の来襲は, 海岸防御の脆弱性を露呈さ せ，前述の江差の様な被災を誘発する可能性がある。

\section{(3) 高波の発達機構}

図-9, 図-10 に低気圧 L1, L2 通過時の有義波高 $H_{s}$ 及 びその発達率 $\mathrm{d} H_{s} / \mathrm{d} t$ の時間変化を示寸. 日本海西部に 位置する低気圧により，日本沿岸には南西の波浪が発 達する，海岸線に沿って北へと伝搬していく高波は，同 じく北上する低気圧による南西風を継続して受け続け るために相対的な吹送時間が長くなり，波はさらに大 きく成長した（図-9, $10(a))$ 。これは低気圧 L1, L2 で 共通して見られた特徵であり, 日本海を北上寸るこの夕 イプの低気圧に伴う高波の重要な発達機構の一つであ ると考えられる．低気圧 L2 については日本海を北上し た後, 北海道西部で停滞しその後ゆっくりと南下した. これにより東北地方沿岸には強い西寄りの風が吹き続 け，9 $\mathrm{m}$ を超える高波が長時間に渡り来襲した（図-10 (a3)) .

低気圧の発達の初期段階においてその周辺では急速 に波高が発達し（図-9, $10(b 1) ）$, 波高の発達は低気圧 の移動に伴い徐々に北へと伝搬した $(b 2, b 3)$. 波高発達 率は外洋で最大 $1.0 \mathrm{~m} / \mathrm{hr}$, 沿岸部では最大 $0.8 \mathrm{~m} / \mathrm{hr}$ 程度 となった（図-11）。永井 ${ }^{6)}$ は各地における 1973-1994 年の間の長期波浪観測データに基き，高波来襲イベン 


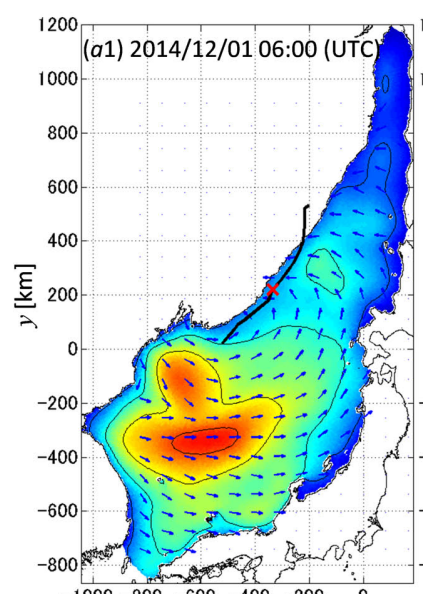

$-1000-800-600-400-200 \quad 0$
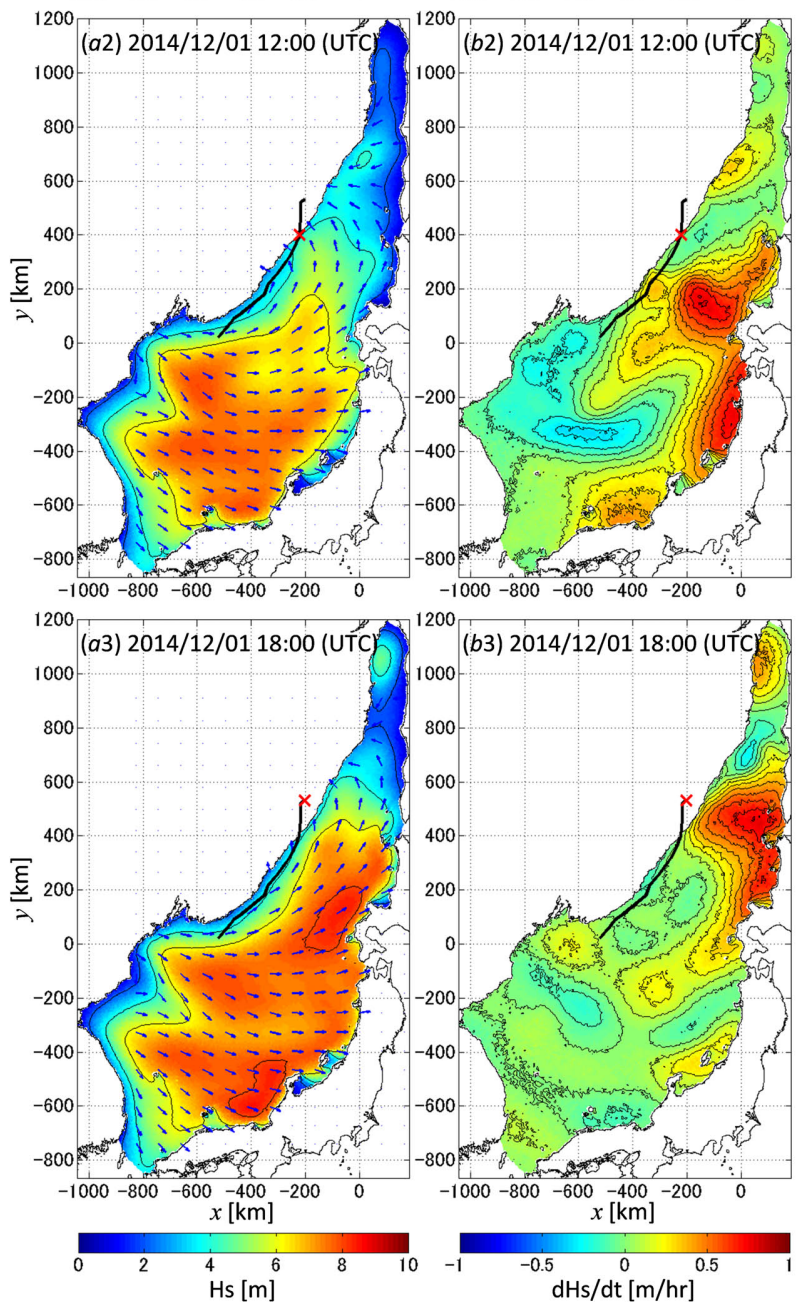

図-9 低気圧 L1 通過に伴う有義波高（左）並びに有義波高発 達率 (右) の時間変化. 黒太線は低気圧の経路，赤 $\times$ 印 は各時刻における低気圧中心位置を表す。

卜時に波高が基準低波高 $H_{l}$ から基準高波高 $H_{h}$ にまで 発達するまでの立ち上がり時間 $t_{s}$ を統計的に調査した. その結果を波高発達率に換算したものと $\left(\left(H_{h}-H_{l}\right) / t_{s}\right)$, 本計算により得られた最大波高発達率を表-1 に示寸. 殆どの地点において L1, L2 通過前の初期波高が基準低
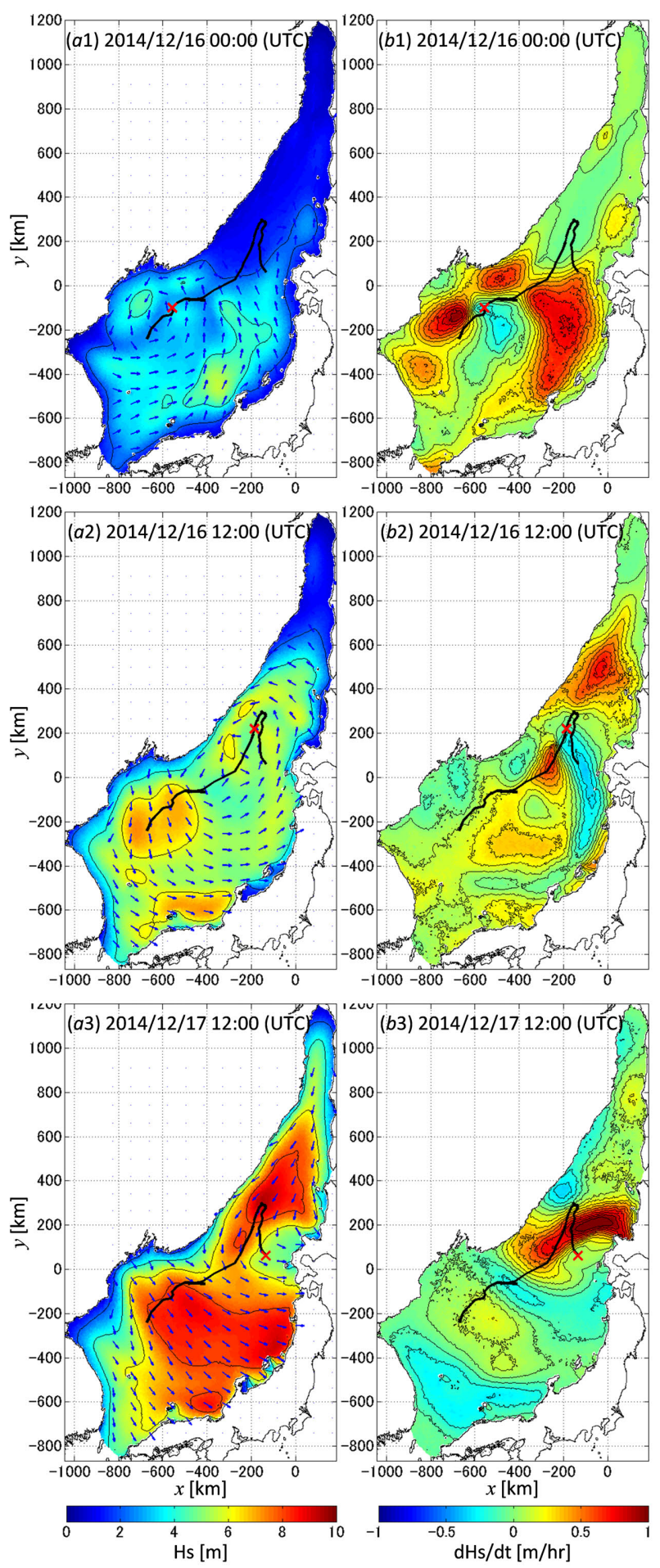

図-10 低気圧 L2 通過に伴う有義波高（左）並びに有義波高 発達率（右）の時間変化. 黒太線は低気圧の経路，赤 ×印は各時刻における低気圧中心位置を表す。

波高よりも高かったため同一の定義による比較はでき ないものの, 本研究で得られた高波発達率は永井 ${ }^{6)}$ に より報告される 1994 年以前の平均波高発達率よりも概 数 1 オーダー程大きかった。本イベントで特徴的だっ た急速な低気圧の発達により高波もまた急速に発達し, 


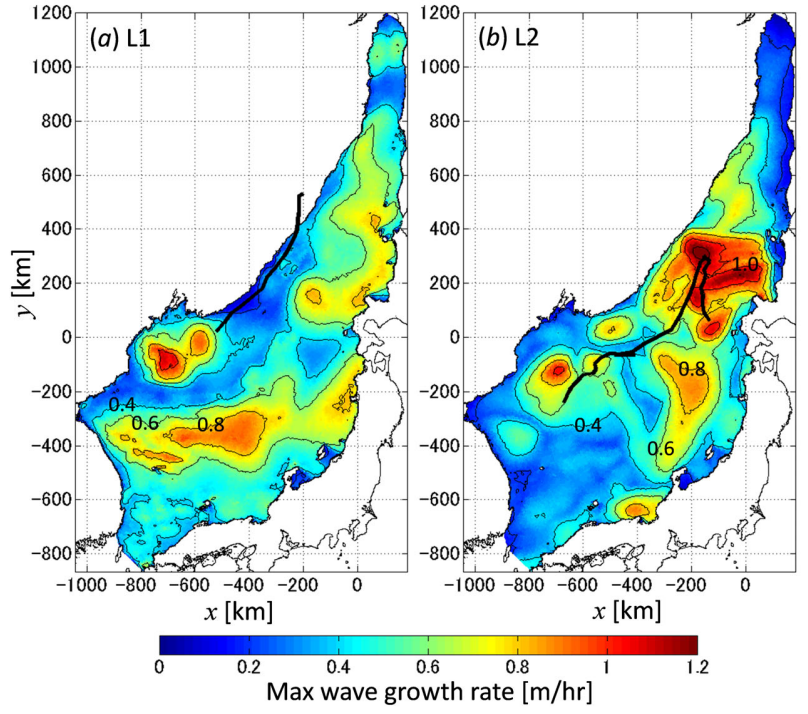

図-11 (a) L1, (b) L2 各イベントにおける有義波高発達率の最 大值の分布．黒太線は各低気圧の中心経路を表す.

平常状態から高波浪状態へと遷移するまでの時間的猶 予が短かったものと考えられる。

以上の様に本研究で対象とした爆弾低気圧に起因す る高波は, 波高発達率や卓越波向等が従来想定されて きたものとは全く異なる特徵を有していた事が明らか となった。

\section{4. 結論}

過去 36 年間の気象再解析データから，日本周辺を 12 月に通過する低気圧の中心気圧は近年減少傾向にあり, それに伴い低気圧が強い勢力を保つ総時間も延長して いることを確認した。また中国地方から北海道にかけ ての日本海側の波浪観測データから，爆弾低気圧通過 時のピーク波高も近年増大傾向にあることが明らかと なった．暴風イベントの強大化と長期化による今後の 更なる高波リスクの増大が懸念される.
2014 年 12 月に日本海上で発達した二つの爆弾低気 圧通過時の高波の発達機構を調査した。 日本沿岸にお ける波向きと低気圧の移動方向が一致する事により相 対的な吹送時間が延長し，本イベントにおける高波は 大きく発達した。急速に発達する低気圧により波も急 速に発達し，波高発達率は 1994 年以前の平均よりも概 ね 1 オーダー程度大きかった。これらの爆弾低気圧は 冬季の典型的な波向きとは異なる方向からの高波を各 地にもたらしたが，想定外の方向からの波は海岸防御 の不充分な地点における高波被害を誘発する危険性が あり，今後の 冬季の日本海沿岸の海岸防御並びに防災 を考える上でこの様なタイプの高波の来襲を新たな外 カパターンとして検討する必要がある.

謝辞： 北海道開発局函館開発建設部より図-1の写真を， 国土交通省港湾局より波浪観測データをご提供頂いた。 ここに謝意を表する。

\section{参考文献}

1) Iwao, K., Inatsu, M., and Kimoto, M.: Recent changes in explosively developing extratropical cyclones over the winter northwestern Pacific, J. Climate, Vol.25, pp.7282-7296, 2012.

2) Sanders, F. and Gyakum, J. R.: Synoptic-dynamic climatology of the "bomb", Mon. Wea. Rev., Vol.108, pp.1589-1606, 1980.

3) Graham, N. E. and Diaz, H. F.: Evidence for intensification of north Pacific winter cyclones since 1948, Bull. Amer. Meteor. Soc., Vol.82, pp.1969-1893, 2001.

4) Booij, N., Ris, R. C., and Holthuijsen, L. H.: A thirdgeneration wave model for coastal regions: 1 . model description and validation, J. Geophys. Res. Oceans, Vol.104, No.C4, pp.7649-7666, 1999.

5) 永井紀彦・菅原一晃・橋本典明・浅井正：全国港湾海洋 波浪観測年報 (NOWPHAS 1991)，港湾技研資料, Vol.745, pp.1-304, 1991 .

6) 永井紀彦: ナウファス（全国港湾海洋波浪情報網）による我 国沿岸の波浪特性の解明, 港湾技研資料, Vol.863, pp.1-113, 1997.

(2015. 3. 18 受付)

\section{MECHANISMS TO DEVELOP HIGH WAVES INDUCED BY AN EXPLOSIVE CYCLOGENESIS OVER THE JAPAN SEA}

\section{Ayumi SARUWATARI and Yasunori WATANABE}

Explosively developing cyclones are becoming one of the important factors affecting winter climate. In recent instances in December 2014, high waves induced by two successive explosive cyclones developed over the Japan Sea hit the wide area along Japanese coasts. In this study, both frequency and duration of explosive winter cyclones as well as wave height during the winter storms are shown to be on an increasing trend for this few years around Japan based on reanalysis and observed data. High waves accompanied by the explosive cyclones in 2014 are found to have completely different features in the wave direction and growth rate from high waves induced by a typical winter monsoon. 